\title{
Lung function in post-poliomyelitis syndrome: a cross-sectional study*
}

\author{
Função pulmonar em pessoas com síndrome pós-poliomielite: um estudo \\ transversal
}

\author{
Claudio Andre Barbosa de Lira, Fábio Carderelli Minozzo, Bolivar Saldanha Sousa, \\ Rodrigo Luiz Vancini, Marília dos Santos Andrade, Abrahão Augusto Juviniano \\ Quadros, Acary Souza Bulle Oliveira, Antonio Carlos da Silva
}

\begin{abstract}
Objective: To compare lung function between patients with post-poliomyelitis syndrome and those with sequelae of paralytic poliomyelitis (without any signs or symptoms of post-poliomyelitis syndrome), as well as between patients with post-poliomyelitis syndrome and healthy controls. Methods: Twenty-nine male participants were assigned to one of three groups: control; poliomyelitis (comprising patients who had had paralytic poliomyelitis but had not developed post-poliomyelitis syndrome); and post-poliomyelitis syndrome. Volunteers underwent lung function measurements (spirometry and respiratory muscle strength assessment). Results: The results of the spirometric assessment revealed no significant differences among the groups except for an approximately $27 \%$ lower mean maximal voluntary ventilation in the post-poliomyelitis syndrome group when compared with the control group $(p=0.0127)$. Nevertheless, the maximal voluntary ventilation values for the post-poliomyelitis group were compared with those for the Brazilian population and were found to be normal. No significant differences were observed in respiratory muscle strength among the groups. Conclusions: With the exception of lower maximal voluntary ventilation, there was no significant lung function impairment in outpatients diagnosed with post-poliomyelitis syndrome when compared with healthy subjects and with patients with sequelae of poliomyelitis without post-poliomyelitis syndrome. This is an important clinical finding because it shows that patients with post-poliomyelitis syndrome can have preserved lung function.
\end{abstract}

Keywords: Respiratory function tests; Postpoliomyelitis syndrome; Muscle strength.

\section{Resumo}

Objetivo: Comparar a função pulmonar de pacientes com síndrome pós-poliomielite à de pacientes com sequelas de poliomielite paralítica (sem quaisquer sinais ou sintomas de síndrome pós-poliomielite) e à de sujeitos saudáveis. Métodos: Vinte e nove sujeitos do sexo masculino foram divididos em três grupos: controle, poliomielite (pacientes que sofreram de poliomielite paralítica, mas que não apresentaram síndrome pós-poliomielite) e síndrome pós-poliomielite. Os voluntários foram submetidos a avaliações da função pulmonar (espirometria e avaliação da força muscular respiratória). Resultados: Os resultados da espirometria não revelaram diferenças significantes entre os grupos, à exceção da ventilação voluntária máxima, cuja média no grupo síndrome pós-poliomielite foi aproximadamente $27 \%$ mais baixa que no grupo controle $(p=0,0127)$. No entanto, os valores de ventilação voluntária máxima observados no grupo pós-poliomielite foram comparados aos da população brasileira e se apresentaram dentro da faixa normal. Não foram observadas diferenças significantes entre os grupos no tocante à força muscular respiratória. Conclusões: À exceção da ventilação voluntária máxima mais baixa, não houve comprometimento significante da função pulmonar em pacientes ambulatoriais com diagnóstico de síndrome pós-poliomielite quando comparados a pacientes com sequelas de poliomielite, mas sem a síndrome pós-poliomielite e a sujeitos saudáveis. Trata-se de um importante achado clínico, pois mostra que pacientes com síndrome pós-poliomielite podem apresentar função pulmonar preservada.

Descritores: Testes de Função Respiratória; Síndrome pós-poliomielite; Força muscular.

*Study carried out at the Federal University of São Paulo, São Paulo, Brazil.

Correspondence to: Claudio Andre Barbosa de Lira. Setor de Fisiologia Humana e do Exercício, Universidade Federal de Goiás, Campus Jataí, Unidade Jatobá, Rodovia BR364, km 192, no. 3800, Parque Industrial, CEP 75801-615 Jataí, G0, Brasil.

Tel. 5564 3606-8301. E-mail: andre.claudio@gmail.com

Financial support: This study was partially supported by Laboratórios Baldacci S/A. Claudio A. B. de Lira is the recipient of a fellowship from the Brazilian Coordenação de Aperfeiçoamento de Pessoal de Nível Superior (CAPES, Office for the Advancement of Higher Education).

Submitted: 11 November 2012. Accepted, after review: 22 July 2013. 


\section{Introduction}

Paralytic poliomyelitis, an acute disease caused by poliovirus, has been part of human history for thousands of years. In the mid-twentieth century, after the introduction of an effective vaccination program, the number of new cases dramatically dropped. Wild-type poliovirus was eliminated from the western hemisphere, and the number of new cases continues to drop in the rest of the world. (1)

Some of the patients with a history of poliomyelitis report late-onset neuromuscular symptoms and a decline in functional capacity. These late symptoms are referred to as postpoliomyelitis syndrome (PPS). The syndrome is characterized by new and increased muscle weakness, fatigue, muscle pain, joint pain, muscle cramps, cold intolerance, and lung problems. ${ }^{(2,3)}$ Although PPS is a common neurological disorder affecting a large proportion of those who have recovered from paralytic poliomyelitis, the causes of PPS remain unclear. The most widely accepted hypothesis, proposed by Wiechers and Hubbell, ${ }^{(4)}$ attributes the symptoms to a distal degeneration of axons from the greatly enlarged motor units that develop during recovery from acute paralytic poliomyelitis.

Patients with PPS have reported respiratory symptoms that include exertional dyspnea and reduced physical endurance..$^{(5-7)}$ Respiratory problems can result from impairment of medullary centers, impairment of cranial nerves, impairment of respiratory muscles, or any combination of the three. ${ }^{(8)}$

The World Health Organization estimates that there are 20 million polio survivors, ${ }^{(9)}$ and new cases of poliomyelitis have been reported in certain African and Asian countries. Therefore, knowledge of lung function in such patients is important in clinical practice in order to provide adequate information regarding their functional status.

The primary objective of the present study was to determine whether individuals with PPS can present with lung function abnormalities. A secondary objective was to compare lung function between patients with PPS and those with sequelae of paralytic poliomyelitis (without any signs or symptoms of PPS), as well as between patients with PPS and healthy controls. Given that patients with PPS commonly experience a significant loss of muscle strength, we hypothesized that they would also show drastic changes in lung function.

\section{Methods}

The present study had a cross-sectional design. Twenty-nine male participants were assigned to one of three groups: control ( $\mathrm{n}=$ 10 ; mean age, $49.8 \pm 2.3$ years; body mass, $88.4 \pm 5.0 \mathrm{~kg}$; and height, $175.4 \pm 1.6 \mathrm{~cm}$ ); poliomyelitis, composed of patients who had had paralytic poliomyelitis but had not developed PPS ( $\mathrm{n}=9$; mean age, $47.9 \pm 2.1$ years; body mass, $81.9 \pm 5.1 \mathrm{~kg}$; and height, $169.0 \pm 2.8$ $\mathrm{cm}$ ); and PPS, composed of patients who had been diagnosed with PPS ( $\mathrm{n}=10$; mean age, $50.2 \pm 2.3$ years; body mass, $71.1 \pm 4.5 \mathrm{~kg}$; and height, $162.9 \pm 2.3 \mathrm{~cm}$ ). Age, body mass, and height were expressed as mean \pm SE. In the poliomyelitis and PPS groups, height was measured with a flexible tape measure, with the patients in the supine position. There were no significant differences among the groups except for lower body mass and height in the PPS group when compared with the control group ( $p<0.05)$. The diagnosis of PPS was based on the method developed by Borg, ${ }^{(10)}$ all patients having been diagnosed by the same neurologist, who has extensive experience in treating patients with PPS. The patients in the poliomyelitis and PPS groups were recruited from among those treated at the Post-Polio Clinic of the Neuromuscular Diseases Section of the Federal University of São Paulo, located in the city of São Paulo, located in the city of São Paulo, Brazil. The clinical profiles of the patients with poliomyelitis sequelae are presented in Table 1 . Healthy controls were recruited from among members of the university community by advertisements placed on the website of the Federal University of São Paulo, located in the city of São Paulo, Brazil, and in local newspapers. All individuals were disease-free except for the residual effects of poliomyelitis, and none were receiving respiratory care. In addition, none of the patients in the poliomyelitis group and only one of those in the PPS group had respiratory complaints. The participants were fully informed of any risks and discomfort associated with the experiments before giving their written consent to participate in the present study, which was approved by the Research Ethics Committee of the Federal University of São Paulo. All procedures were in accordance with the principles of the Declaration of Helsinki. 
We assessed lung function by spirometry and by assessing respiratory muscle strength. All lung function tests were performed with the subjects sitting upright. A trained laboratory technician demonstrated each respiratory maneuver to each subject before initiating the test.

Spirometry was performed using a $\mathrm{K} 4 \mathrm{~b}^{2}$ spirometer (Cosmed, Rome, 1taly) attached to a computer. Our interpretation was based on the American Thoracic Society/European Respiratory Society guidelines. ${ }^{(11)}$ On the day of the test, the volunteers did not undergo any physical exercise. They were instructed to perform 3-5 maximal forced expiratory maneuvers, a 3-min interval being allowed between trials. The outcomes of interest were FVC, FEV $\mathrm{FEV}_{1} / \mathrm{FVC}$ ratio, PEF, $\mathrm{FEF}_{25-75 \%}$, and maximal voluntary ventilation (MVV), the highest value for each being used for data analysis. In order to measure MVV, subjects were required to breathe as deeply and rapidly as possible for $12 \mathrm{~s}$. The respiratory volume values were then extrapolated to $1 \mathrm{~min}$.

Our spirometer was calibrated at least daily with a 3-L syringe (Hans Rudolf, Inc., Shawnee, KS, USA). All calibrations were within 1\% measurement error. All volumes were corrected for body temperature, ambient pressure, and saturation with water vapor. Spirometric variables were compared with reference values for the Brazilian population. ${ }^{(12,13)}$

Respiratory muscle strength was assessed by measuring MIP and MEP with a manometer (GerAr, São Paulo, Brazil), resolution being 1 $\mathrm{cmH}_{2} \mathrm{O}$ and capacity being $300 \mathrm{cmH}_{2} \mathrm{O}$. A small $(<2 \mathrm{~mm})$ opening close to the mouthpiece was used in order to decrease mouth pressure and prevent patients from using their cheeks to generate pressure.

For the measurement of MIP, participants emptied their lungs by blowing as hard as possible and exhaling as much air as possible to RV, subsequently inhaling up to TLC. The highest recorded value was used for analysis. For the measurement of MEP, participants were asked to fill their lungs with as much air as possible up to TLC and then rapidly breathe out. The measurements were repeated with 1-min intervals between trials. The highest pressure of each set of 3 trials was recorded. The obtained values were expressed in $\mathrm{cmH}_{2} \mathrm{O}$ and compared with reference values for the Brazilian population. ${ }^{(13)}$

Regarding statistical analysis, normal distribution and homogeneity of variance were determined by the Kolmogorov-Smirnov test and the Levene test, respectively. The values obtained in the lung function tests were converted to percentages of the predicted values. To that end, the reference values for FVC, $\mathrm{FEV}_{1}$, the $\mathrm{FEV}_{1} / \mathrm{FVC}$ ratio, $\mathrm{PEF}$, and $\mathrm{FEF}_{25-75 \%}$ were based on those used by Pereira et al. for the Brazilian population, ${ }^{(12)}$ whereas those for MVV, MIP, and MEP were based on values used by Neder et al. ${ }^{(13)}$

The age at onset of acute poliomyelitis and the number of years of functional stability were compared between the poliomyelitis and PPS groups by the Student's t-test for unpaired samples. Another Student's t-test for unpaired samples was performed in order to compare the obtained and predicted values for the following respiratory variables: FVC, $\mathrm{FEV}_{1}$, the $\mathrm{FEV}_{1} / \mathrm{FVC}$ ratio, PEF, $\mathrm{FEF}_{25-75 \%}$, MVV, MIP, and MEP. Subsequently, a one-way ANOVA was performed in order to detect differences in respiratory variables among the groups. When a significant effect was achieved, Tukey's post hoc test was performed in order to detect differences among the means. Data are presented as mean \pm SE. The significance level was set at 0.05 for all statistical procedures.

Table 1 - Clinical profiles of patients with poliomyelitis sequelae. ${ }^{a}$

\begin{tabular}{lcc}
\hline Variable & $\begin{array}{c}\text { Poliomyelitis } \\
\text { group }\end{array}$ & PPS group \\
\cline { 2 - 3 } & $(\mathrm{n}=9)$ & $(\mathrm{n}=10)$ \\
\hline Age at onset (years) & $1.6 \pm 0.4$ & $1.5 \pm 0.3$ \\
Years of functional & $40.0 \pm 3.0$ & $35.3 \pm 3.0$ \\
stability & $\mathrm{N} / \mathrm{A}$ & $7.3 \pm 1.4$ \\
Years of PPS & & \\
\hline Physical sequelae & 6 & 2 \\
Monoparesis & 1 & 3 \\
Diparesis & 0 & 2 \\
Triparesis & 0 & 2 \\
Quadriparesis & 2 & 1 \\
Hemiparesis & & \\
\hline
\end{tabular}

PPS: post-poliomyelitis syndrome. ${ }^{\text {aValues expressed as }}$ mean \pm SE. 
Table 2 - Spirometric assessment in controls and patients with poliomyelitis sequelae. ${ }^{2}$

\begin{tabular}{lcccc}
\hline Variable & & CG $(\mathrm{n}=10)$ & $\mathrm{PG}(\mathrm{n}=9)$ & PPSG $(\mathrm{n}=10)$ \\
\hline FVC & Obtained (L) & $4.75 \pm 0.23$ & $4.20 \pm 0.16$ & $3.91 \pm 0.34$ \\
& Predicted (L) & $4.64 \pm 0.14$ & $4.30 \pm 0.17$ & $3.89 \pm 0.16$ \\
& \% of predicted & $102.80 \pm 5.28$ & $98.45 \pm 4.25$ & $100.70 \pm 8.52$ \\
\hline FEV ${ }_{1}$ & Obtained (L) & $3.81 \pm 0.19$ & $3.47 \pm 0.15$ & $3.20 \pm 0.24$ \\
& Predicted (L) & $3.75 \pm 0.12$ & $3.51 \pm 0.13$ & $3.15 \pm 0.14$ \\
& \% of predicted & $101.80 \pm 4.27$ & $99.81 \pm 4.65$ & $102.30 \pm 7.58$ \\
\hline FEV $/$ FVC & Obtained (\%) & $80.72 \pm 2.63$ & $82.77 \pm 2.36$ & $83.08 \pm 2.15$ \\
& Predicted (\%) & $80.79 \pm 0.45$ & $81.51 \pm 0.56$ & $80.80 \pm 0.57$ \\
& \% of predicted & $99.87 \pm 3,06$ & $101.5 \pm 2.45$ & $102.8 \pm 2.38$ \\
\hline FEF ${ }_{25-75 \%}$ & Obtained (L/s) & $4.18 \pm 0.44$ & $3.93 \pm 0.44$ & $3.51 \pm 0.28$ \\
& Predicted (L/s) & $3.69 \pm 0.18$ & $3.51 \pm 0.12$ & $3.17 \pm 0.16$ \\
& \% of predicted & $112.60 \pm 10.03$ & $111.60 \pm 11.32$ & $111.90 \pm 8.01$ \\
\hline PEF & Obtained (L/s) & $10.17 \pm 0.45$ & $10.03 \pm 0.48$ & $9.22 \pm 0.68$ \\
& Predicted (L/s) & $9.37 \pm 0.22$ & $8.87 \pm 0.26$ & $8.21 \pm 0.26$ \\
& \% of predicted & $108.60 \pm 4.43$ & $113.00 \pm 3.91$ & $112.90 \pm 8.47$ \\
\hline MVV & Obtained (L/min) & $168.90 \pm 10.00$ & $150.50 \pm 10.70$ & $123.50 \pm 10.00^{*}$ \\
& Predicted (L/min) & $143.40 \pm 2.50$ & $146.00 \pm 2.50$ & $142.90 \pm 2.60$ \\
& \% of predicted & $117.40 \pm 5.60$ & $103.00 \pm 6.90$ & $86.50 \pm 6.90^{*}$ \\
\hline
\end{tabular}

CG: control group; PG: poliomyelitis group; PPSG: post-poliomyelitis syndrome group; and MVV: maximal voluntary ventilation. ${ }^{a}$ Data expressed as mean $\pm \mathrm{SE}$. ${ }^{*} \mathrm{p}<0.05$, significantly different from the control group.

Table 3 - Respiratory muscle strength in controls and patients with poliomyelitis sequelae. ${ }^{2}$

\begin{tabular}{lcccc}
\hline Variable & CG $(\mathrm{n}=10)$ & PG $(\mathrm{n}=9)$ & PPSG $(\mathrm{n}=10)$ \\
\hline MIP & Obtained $\left(\mathrm{cmH}_{2}\right)$ & $150 \pm 14$ & $136 \pm 13$ & $118 \pm 12$ \\
& Predicted $\left(\mathrm{cmH}_{2}\right)$ & $116 \pm 2$ & $117 \pm 2$ & $115 \pm 2$ \\
& \% of predicted & $130 \pm 12$ & $115 \pm 10$ & $103 \pm 11$ \\
\hline MEP & Obtained $\left(\mathrm{cmH}_{2} 0\right)$ & $181 \pm 17$ & $180 \pm 11$ & $146 \pm 15$ \\
& Predicted $\left(\mathrm{cmH}_{2}\right)$ & $125 \pm 2$ & $127 \pm 2$ & $125 \pm 2$ \\
& \% of predicted & $144 \pm 13$ & $142 \pm 9$ & $118 \pm 13$ \\
\hline
\end{tabular}

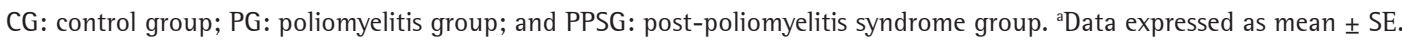

\section{Results}

No significant differences were observed between the poliomyelitis and PPS groups regarding the age at onset of acute poliomyelitis or the number of years of functional stability (Table 1). The results of the spirometric assessment are shown in Table 2. No significant differences were observed among the groups except for an approximately 27\% lower mean MVV in the PPS group when compared with the control group (p $=0.0127)$. Nevertheless, the MVV values obtained in the PPS group were compared with those for the Brazilian population and were found to be normal. Regarding respiratory muscle strength, no significant differences were observed among the groups (Table 3).

\section{Discussion}

After the implementation of an effective worldwide vaccination program, paralytic poliomyelitis was virtually forgotten by the medical community. However, millions of polio survivors still need special care and clinical assistance. These survivors have complained about new signs and symptoms, which are collectively known as PPS. Because the major polio epidemics occurred in the 1950s in many western countries and in the 1980s in Latin American countries, and considering that late-onset neurological changes typically do not appear until 30-50 years after infection, millions of polio survivors had not experienced problems related to their poliomyelitis sequelae 
until the late 1970s and early 1980s. People experiencing these symptoms are now receiving attention from the medical community in several parts of the world. In fact, as a result of an initiative led by professionals from the Federal University of São Paulo, PPS was included in the International Classification of Diseases. Additionally, new cases of polio have been reported in certain African and Asian countries. Therefore, studies investigating the clinical profile of PPS are important to elucidate the pathological mechanisms and clinical impact of this neuromuscular disease.

In the present study, we investigated the lung function of patients with sequelae of paralytic poliomyelitis with and without PPS. Our results showed that there were no significant differences among the groups (control, poliomyelitis, and PPS).

To our knowledge, this is the first study to investigate lung function in patients with paralytic poliomyelitis divided into groups of patients with PPS (the PPS group) and without PPS (the poliomyelitis group). Previously, many studies investigating lung function in patients with poliomyelitis sequela $\mathrm{e}^{(8,14-18)}$ and other neuromuscular diseases ${ }^{(19)}$ were controversial because of the differences among patients in terms of their characteristics, which are usually dependent on the degree of impairment, the origin of the patients (outpatients having less disease progression), gender, and the presence of respiratory complaints.

Our results showed no lung function impairment due to late sequelae of paralytic poliomyelitis. They are in disagreement with those of previous studies evaluating respiratory function in the same types of patients. ${ }^{(8,15,18)}$ However, those studies evaluated patients with a history of poliomyelitis and respiratory problems, in whom lung function was found to be markedly lower. In our study, none of the patients in the poliomyelitis group had any respiratory complaints and only one of those in the PPS group complained of dyspnea on exertion.

It is known that MVV is partially dependent on respiratory muscle strength and endurance. ${ }^{(20)}$ In fact, Knobil et al. ${ }^{(17)}$ reported the case of a patient with decreased MVV associated with low MIP. In our study, MVV was significantly lower in the PPS group than in the control group. However, the
MVV values found in the PPS group were found to be normal after having been compared with those for the Brazilian population. We found no significant differences in respiratory muscle strength (as assessed by MIP and MEP) among the groups. This might explain why the MVV values in our study were not significantly different from the reference values for the Brazilian population.

In general, lung function was not affected in the patients with poliomyelitis sequelae investigated in our study, a finding that is in disagreement with those of a previous study. ${ }^{(21)}$ In that study, lung function impairment in those patients was associated with hospitalization, need for mechanical ventilation during the acute stage of the disease, age at disease acquisition (10 years or older), presence of quadriparesis, and time of exposure to the disease. In our study, only one of the individuals in the PPS group and two of those in the poliomyelitis group required hospitalization and respiratory support. In addition, none of the affected individuals had had poliomyelitis at an age older than 10 years (the mean age at disease acquisition being 1.6 in the poliomyelitis group and 1.5 years in PPS group), and only two of the individuals in the poliomyelitis group and three of those in the PPS group had quadriparesis. Lung function impairment has been strongly correlated with dyspnea. (8) In our study, none of the patients in the poliomyelitis group and one of those in the PPS group complained of dyspnea on exertion, having no other respiratory complaints.

In conclusion, with the exception of lower MVV, there were no significant differences in lung function between the group of patients with PPS and that of those with poliomyelitis or between the former and healthy controls. This is an important clinical finding because it shows that patients with PPS can have preserved lung function.

\section{Acknowledgments}

We thank the multidisciplinary team at the Neuromuscular Diseases Section of the Federal University of São Paulo Department of Neurology and Neurosurgery for the patient referrals. We also thank all of the individuals who volunteered to participate in the present study. 


\section{References}

1. John TJ. The final stages of the global eradication of polio. N Engl J Med. 2000;343(11):806-7. http://dx.doi. org/10.1056/NEJM200009143431111 PMid:10984572

2. Trojan DA, Cashman NR. Post-poliomyelitis syndrome. Muscle Nerve. 2005;31(1):6-19. http://dx.doi.org/10.1002/ mus.20259 PMid:15599928

3. Tiffreau V, Rapin A, Serafi R, Percebois-Macadré L, Supper C, Jolly D, et al. Post-polio syndrome and rehabilitation. Ann Phys Rehabil Med. 2010;53(1):42-50. http://dx.doi. org/10.1016/j.rehab.2009.11.007 PMid:20044320

4. Wiechers D0, Hubbell SL. Late changes in the motor unit after acute poliomyelitis. Muscle Nerve. 1981;4(6):524-8. http://dx.doi.org/10.1002/mus.880040610 PMid:6273721

5. Cosgrove JL, Alexander MA, Kitts EL, Swan BE, Klein MJ, Bayer RE. Late effects of poliomyelitis. Arch Phys Med Rehabil. 1987;68(1):4-7. PMid:3800623

6. Fischer DA. Poliomyelitis: late respiratory complications and management. Orthopedics. 1985;8(7):891-4. PMid:3867866

7. Hamilton EA, Nichols PJ, Tait GB. Late onset of respiratory insufficiency after poliomyelitis. Ann Phys Med. 1970;10(5):223-9. PMid:4392215

8. Dean E, Ross J, Road JD, Courtenay L, Madill KJ. Pulmonary function in individuals with a history of poliomyelitis. Chest. 1991;100(1):118-23. http://dx.doi.org/10.1378/ chest.100.1.118 PMid:2060329

9. Aylward RB, Hull HF, Cochi SL, Sutter RW, Olivé JM, Melgaard B. Disease eradication as a public health strategy: a case study of poliomyelitis eradication. Bull World Health Organ. 2000;78(3):285-97. PMid:10812724 PMCid:PMC2560720

10. Borg K. Post-polio muscle dysfunction 29th ENMC workshop 14-16 October 1994, Naarden, the Netherlands. Neuromuscul Disord. 1996;6(1):75-80. http://dx.doi. org/10.1016/0960-8966(95)00013-5

11. Miller MR, Hankinson J, Brusasco V, Burgos F, Casaburi $R$, Coates A, et al. Standardisation of spirometry. Eur Respir J. 2005;26(2):319-38. http://dx.doi.org/10.118 3/09031936.05.00034805 PMid:16055882
12. Pereira CAC, Barreto SP, Simões JG, Pereira FWL, Gerstler JG, Nakatani J. Valores de referência para espirometria em uma amostra da população brasileira adulta. J Pneumol 1992,18(1):10-22.

13. Neder JA, Andreoni S, Lerario MC, Nery LE. Reference values for lung function tests. 11. Maximal respiratory pressures and voluntary ventilation. Braz J Med Biol Res. 1999;32(6):719-27. http://dx.doi.org/10.1590/ S0100-879X1999000600007 PMid:10412550

14. Borg K, Kaijser L. Lung function in patients with prior poliomyelitis. Clin Physiol. 1990;10(2):201-12. http:// dx.doi.org/10.1111/j.1475-097X.1990.tb00254.x

15. Blomstrand A, Bake B. Post-polio lung function. Scand J Rehabil Med. 1992;24(1):43-9. PMid:1604261

16. Stanghelle JK, Festvåg L, Aksnes AK. Pulmonary function and symptom-limited exercise stress testing in subjects with late sequelae of poliomyelitis. Scand J Rehabil Med. 1993;25(3):125-9. PMid:8248763

17. Knobil K, Becker FS, Harper P, Graf LB, Wolf GT, Martinez FJ. Dyspnea in a patient years after severe poliomyelitis. The role of cardiopulmonary exercise testing. Chest. 1994;105(3):777-81. http://dx.doi.org/10.1378/ chest.105.3.777 PMid:8131540

18. Soliman MG, Higgins SE, El-Kabir DR, Davidson AC, Williams AJ, Howard RS. Non-invasive assessment of respiratory muscle strength in patients with previous poliomyelitis. Respir Med. 2005;99(10):1217-22. http:// dx.doi.org/10.1016/j.rmed.2005.02.035 PMid:16140221

19. Paschoal IA, Villalba Wde O, Pereira MC. Chronic respiratory failure in patients with neuromuscular diseases: diagnosis and treatment. J Bras Pneumol. 2007;33(1):81-92. http://dx.doi.org/10.1590/S1806-37132007000100016 PMid:17568873

20. Heliopoulos I, Patlakas G, Vadikolias K, Artemis N, Kleopa $\mathrm{KA}$, Maltezos E, et al. Maximal voluntary ventilation in myasthenia gravis. Muscle Nerve. 2003;27(6):715-9. http://dx.doi.org/10.1002/mus.10378 PMid:12766983

21. Halstead LS, Rossi CD. New problems in old polio patients: results of a survey of 539 polio survivors. Orthopedics. 1985;8(7):845-50. PMid:3867865

\title{
About the authors
}

\section{Claudio Andre Barbosa de Lira}

Adjunct Professor. Federal University of Goiás at Jataí, Jataí, Brazil.

Fábio Carderelli Minozzo

Postdoctoral Fellow. McGill University, Montreal, Canada.

\section{Bolivar Saldanha Sousa}

Physician. Faculdade de Ciências Médicas da Santa Casa de São Paulo and Instituto lsraelita de Ensino e Pesquisa Albert Einstein, São Paulo, Brazil.

\section{Rodrigo Luiz Vancini}

Adjunct Professor. Federal University of Goiás at Jataí, Jataí, Brazil.

\section{Marília dos Santos Andrade}

Adjunct Professor. Department of Physiology, Federal University of São Paulo, São Paulo, Brazil.

\author{
Abrahão Augusto Juviniano Quadros \\ Physiotherapist. Department of Neurology and Neurosurgery, Federal University of São Paulo, São Paulo, Brazil.
}

Acary Souza Bulle Oliveira

Physician. Department of Neurology and Neurosurgery, Federal University of São Paulo, São Paulo, Brazil.

\section{Antonio Carlos da Silva}

Associate Professor. Department of Physiology, Federal University of São Paulo, São Paulo, Brazil. 